\title{
A COMPARATIVE STUDY OF COLLAGEN DRESSINGS VERSUS CONVENTIONAL DRESSINGS IN WOUND HEALING IN CHRONIC ULCER
}

\author{
Deepak Choudhary1, Swapnil Garg Insen², Sandeep Goyal33, Umesh Chabbra4, Gopal Singal ${ }^{5}$ \\ ${ }^{1}$ Senior Resident, Department of General Surgery, Maharaja Agrasen Medical College, Agroha, Hisar, Haryana. \\ ${ }_{2}^{2}$ Associate Professor, Department of General Surgery, Maharaja Agrasen Medical College, Agroha, Hisar, Haryana. \\ ${ }^{3}$ Assistant Professor, Department of General Surgery, Maharaja Agrasen Medical College, Agroha, Hisar, Haryana. \\ ${ }_{4}^{4}$ Associate Professor, Department of General Surgery, Maharaja Agrasen Medical College, Agroha, Hisar, Haryana. \\ 5 Professor, Department of General Surgery, Maharaja Agrasen Medical College, Agroha, Hisar, Haryana.
}

\begin{tabular}{l}
\hline ABSTRACT \\
\hline BACKGROUND \\
Chronic ulcers are defined as a slow or non-healing breakdown of epidermal and dermal tissue that lasts more than 6 weeks. \\
Regardless of aetiology, chronic ulcers cause considerable and prolonged distress for patients. The use of newer dressings with \\
collagen dressing may increase the wound-healing potentials. \\
$\quad$ The aim of this study is to compare the efficacy of collagen dressing with that of conventional dressing in the management of \\
chronic ulcers and their healing process.
\end{tabular}

\section{MATERIALS AND METHODS}

Prospective study was done on 60 patients who visited the surgery OPD or were admitted for chronic ulcers in Surgery Department. For 30 patients, collagen dressing was done and for rest conventional dressing. The recorded data from the patient's files regarding characteristics of ulcer as size, edge, floor characteristics, slough, granulation tissue, pathogenic organisms and wound swab or pus culture sensitivity results were noted and analysed.

\section{RESULTS}

The granulation tissue appeared in around 2 weeks in maximum cases in collagen dressing group, i.e. $63.4 \%$ and in around 4 weeks in conventional dressing group i.e. $46.7 \%$. Average time for appearance of granulation tissue in collagen and conventional dre ssing group was around 3 weeks and 4.9 weeks respectively. Infection rate in our study in collagen and conventional dressing group was $6.67 \%$ and $13.33 \%$ respectively.

\section{CONCLUSION}

From above study, we concluded that collagen dressing is better than conventional dressing for the management of chronic ulcers.

\section{KEYWORDS}

Collagen, Conventional, Chronic.

HOW TO CITE THIS ARTICLE: Choudhary D, Insen SG, Goyal S, et al. A comparative study of collagen dressings versus conventional dressings in wound healing in chronic ulcer. J. Evolution Med. Dent. Sci. 2017;6(5):361-363, DOI: $10.14260 /$ Jemds/2017/82

\section{BACKGROUND \\ Chronic ulcers are defined as a slow or non-healing breakdown of epidermal and dermal tissue that lasts more than 6 weeks. Regardless of aetiology, chronic ulcers cause considerable and prolonged distress for patients. The use of newer dressings with collagen dressing may increase the wound-healing potentials. Study is conducted to compare the efficacy of collagen dressing with that of conventional dressing in the management of chronic ulcers and their healing process.}

\section{MATERIALS AND METHODS}

A prospective study was conducted on patients with chronic ulcers attending the Department of Surgery, Maharaja Agrasen Medical College, Agroha (Hisar).

Financial or Other, Competing Interest: None.

Submission 10-12-2016, Peer Review 02-01-2017,

Acceptance 09-01-2017, Published 16-01-2017.

Corresponding Author:

Dr. Deepak Choudhary,

Flat No-42, New Campus,

Maharaja Agrasen Medical College,

Agroha, Hisar.

E-mail:drdeepak29@yahoo.com

DOI: $10.14260 /$ jemds $/ 2017 / 82$
Conventional dressing is done using normal saline, sterilised cotton and gauze, bandages, sterilised pus swabs for culture and sensitivity tests. For collagen dressing we used collagen granules/sheet, normal saline, sterile gauze pieces, sterilised pus swabs for culture and sensitivity tests. Patients included were patients with non-infected chronic ulcers, ready to give consent with or without diabetes. The pus samples were processed in the Microbiology Department by standard procedures. The study consisted of 60 patients coming to the surgical ward of Maharaja Agrasen Medical College, Agroha (Hisar), in which collagen dressing was done for 30 patients and conventional dressing for another 30 patients.

Patient admitted first was taken in the conventional group, the second into the collagen group and so on. In all cases, a relevant history of illness was recorded. A detailed general and local examination was conducted along with routine investigations. Before applying collagen dressing, the affected area was thoroughly cleaned, then collagen dressing was applied. A saline soaked sterilised gauze piece was placed over the dressing and covered with a bandage. The collagen dressing (granules) was changed every $3^{\text {rd }}$ to $5^{\text {th }}$ day. Pus swab for culture and sensitivity was taken as a routine investigation. The collagen dressing was applied over the wound surface for a maximum period of 12 weeks. 
Ulcers of the patients in the conventional group were dressed with normal saline under complete aseptic methods and dressing was changed on alternate day or daily depending upon condition of ulcer.

All patients were instructed to return for followup and were re-evaluated weekly, till wound was healed or up to 12 weeks.

Response to the treatment and patient's outcome were noted in terms of progression of wound healing, granulation tissue formation, changes in edges of wounds and need of skin grafts.

Data hence collected was entered in Microsoft Excel 2007 and then transferred to SPSS version 20.0 for analysis. Data were described using descriptive data like mean and percentage. Test of significance was done using Chi-square test and Fisher exact test. P-value of $<0.05$ was taken as significant.

\section{RESULTS}

Table 1 shows that average age in both collagen and conventional group was 47 years. Maximum patients were in between 41 to 60 years range.

Most common type of ulcer in this study was traumatic followed by diabetic ulcer.

Table 4 shows that most ulcers were less than $20 \mathrm{~cm}^{2}$, i.e. around $66.7 \%$ and $63.3 \%$ in collagen and conventional dressing groups respectively. There was no significant difference in ulcer size in both the groups.

Table 6 shows that granulation tissue appeared early in case of collagen dressing. Average time taken in collagen and conventional dressing was 3 weeks and 4.9 weeks respectively. $P$ value is 0.002 , which is statistically significant. So, reduction of healing time by $39 \%$ in chronic ulcers in collagen dressing group.

As per Table 7 overall infection rate in the study was $20 \%$, out of which collagen dressing group contributed only $6.67 \%$ and conventional dressing group $13.33 \%$; $p$ value was $<0.00$ which was highly significant. This suggests that collagen group had higher safety profile.

There is no relationship of appearance of granulation tissue with age of the patient and size of ulcer as Pearson correlation coefficient signifies weak correlation.

\begin{tabular}{|c|c|c|}
\hline $\begin{array}{c}\text { Age } \\
\text { (In Years) }\end{array}$ & $\begin{array}{c}\text { Collagen Dressing } \\
\text { No. (Percentage) }\end{array}$ & $\begin{array}{c}\text { Conventional Dressing } \\
\text { No. (Percentage) }\end{array}$ \\
\hline $0-20$ & $1(3.34 \%)$ & $3(10 \%)$ \\
\hline $21-40$ & $10(33.33 \%)$ & $9(30 \%)$ \\
\hline $41-60$ & $16(53.33 \%)$ & $13(43.33 \%)$ \\
\hline $61-80$ & $3(10 \%)$ & $4(13.33 \%)$ \\
\hline$>80$ & 0 & $1(3.34 \%)$ \\
\hline Average & 47 years & 47 years \\
\hline \multicolumn{3}{|c|}{ Table 1. Age Distribution } \\
\hline
\end{tabular}

\begin{tabular}{|c|c|c|}
\hline Sex & $\begin{array}{c}\text { Collagen Dressing } \\
\text { No. (Percentage) }\end{array}$ & $\begin{array}{c}\text { Conventional Dressing } \\
\text { No. (Percentage) }\end{array}$ \\
\hline Male & $25(83.4 \%)$ & $25(83.4 \%)$ \\
\hline Female & $5(16.6 \%)$ & $5(16.6 \%)$ \\
\hline \multicolumn{3}{|c|}{ Table 2. Sex Ratio } \\
\hline Type & $\begin{array}{c}\text { Collagen Dressing } \\
\text { No. (Percentage) }\end{array}$ & $\begin{array}{c}\text { Conventional Dressing } \\
\text { No. (Percentage) }\end{array}$ \\
\hline
\end{tabular}

\begin{tabular}{|c|c|c|}
\hline Traumatic & $23(76.7 \%)$ & $25(83.4 \%)$ \\
\hline Diabetic & $5(16.7 \%)$ & $3(10 \%)$ \\
\hline Pressure & $1(3.3 \%)$ & $1(3.3 \%)$ \\
\hline Venous & $1(3.3 \%)$ & $1(3.3 \%)$ \\
\hline \multicolumn{2}{|c|}{ Table 3. Type of Ulcers } \\
\hline
\end{tabular}

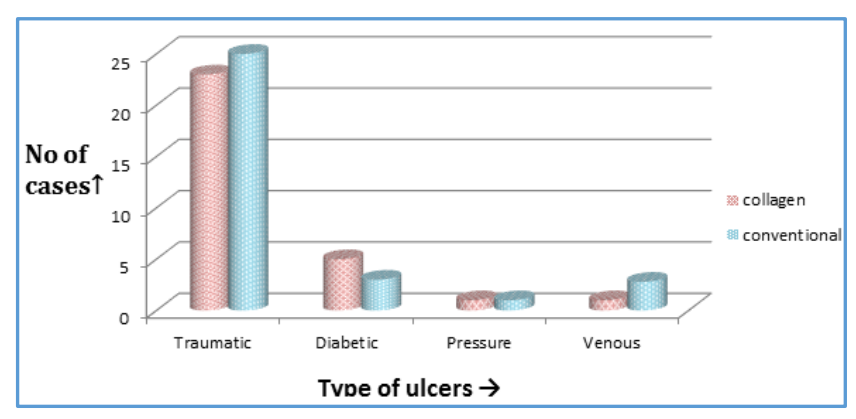

Figure 1

\begin{tabular}{|c|c|c|}
\hline \begin{tabular}{|c|}
$\begin{array}{c}\text { Size of Ulcer } \\
\left(\mathrm{cm}^{2}\right)\end{array}$ \\
\end{tabular} & \begin{tabular}{|l|} 
Collagen Dressing \\
No. (Percentage) \\
\end{tabular} & $\begin{array}{c}\text { Conventional Dressing } \\
\text { No. (Percentage) } \\
\end{array}$ \\
\hline $1-20$ & $20(66.7 \%)$ & $19(63.3 \%)$ \\
\hline $21-40$ & $6(20 \%)$ & $7(23.3 \%)$ \\
\hline $41-60$ & $3(10 \%)$ & $2(6.7 \%)$ \\
\hline $61-80$ & 0 & $2(6.7 \%)$ \\
\hline$>80$ & $1(3.3 \%)$ & 0 \\
\hline Average & $22.9 \mathrm{~cm}^{2}$ & $23.7 \mathrm{~cm}^{2}$ \\
\hline \multicolumn{3}{|c|}{ Table 4. Size of Ulcers } \\
\hline
\end{tabular}

\begin{tabular}{|c|c|c|}
\hline $\begin{array}{c}\text { Duration } \\
\text { (Weeks) }\end{array}$ & $\begin{array}{c}\text { Collagen Dressing } \\
\text { No. (Percentage) }\end{array}$ & $\begin{array}{c}\text { Conventional Dressing } \\
\text { No. (Percentage) }\end{array}$ \\
\hline $6-8$ & $21(70 \%)$ & $20(66.7 \%)$ \\
\hline $8-10$ & $4(13.4 \%)$ & $5(16.7 \%)$ \\
\hline $10-12$ & $3(10 \%)$ & $2(6.7 \%)$ \\
\hline $12-14$ & 0 & 0 \\
\hline $14-16$ & $1(3.3 \%)$ & $1(3.3 \%)$ \\
\hline$>16$ & $1(3.3 \%)$ & $2(6.6 \%)$ \\
\hline Median & 9.2 Weeks & 8.8 Weeks \\
\hline \multicolumn{3}{|c|}{ Table 5. Duration of Ulcers } \\
\hline
\end{tabular}

\begin{tabular}{|c|c|c|}
\hline $\begin{array}{c}\text { Duration } \\
\text { (Weeks) }\end{array}$ & $\begin{array}{c}\text { Collagen Dressing } \\
\text { No. (Percentage) }\end{array}$ & $\begin{array}{c}\text { Conventional Dressing } \\
\text { No. (Percentage) }\end{array}$ \\
\hline 2 & $19(63.4 \%)$ & $11(36.7 \%)$ \\
\hline 4 & $10(33.3 \%)$ & $14(46.7 \%)$ \\
\hline 12 & $1(3.3 \%)$ & $4(13.3 \%)$ \\
\hline$>12$ & 0 & $1(3.3 \%)$ \\
\hline Average & 3 Weeks & 4.9 Weeks \\
\hline \multicolumn{2}{|c|}{ Table 6. Appearance of Granulation Tissue } \\
\hline
\end{tabular}

\begin{tabular}{|c|c|c|}
\hline $\begin{array}{c}\text { Infection Rate } \\
\text { (Overall) }\end{array}$ & $\begin{array}{c}\text { Collagen } \\
\text { Dressing } \\
\text { No. } \\
\text { (Percentages) }\end{array}$ & $\begin{array}{c}\text { Conventional } \\
\text { Dressing } \\
\text { No. (Percentages) }\end{array}$ \\
\hline $12(20 \%)$ & $4(6.67 \%)$ & $8(13.33 \%)$ \\
\hline \multicolumn{3}{|c|}{ Table 7. Wound Infection } \\
\hline
\end{tabular}

\begin{tabular}{|c|c|c|}
\hline Grafting & $\begin{array}{c}\text { Collagen } \\
\text { No. (Percentage) }\end{array}$ & $\begin{array}{c}\text { Conventional } \\
\text { No. (Percentage) }\end{array}$ \\
\hline Yes & $23(76.67 \%)$ & $25(83.33 \%)$ \\
\hline No & $7(23.33 \%)$ & $5(16.67 \%)$ \\
\hline \multicolumn{2}{|c|}{ Table 8. Requirement of Split Skin Grafting } \\
\hline
\end{tabular}




\section{DISCUSSION}

Chronic ulcers are defined as a slow or non-healing breakdown of epidermal and dermal tissue that lasts more than 6 weeks. Majority of ulcers are associated with venous disease, peripheral arterial disease, mixed arteriovenous disease and diabetes. Women suffer more than men from lower limb ulcers, outnumbering them by a ratio of more than $2: 1{ }^{1}$ Wound healing is a complex process that involves the timely expression of numerous growth factors that promote cellular migration and proliferation, production of new connective tissue matrix and collagen deposition. ${ }^{2}$ In addition, chronic wounds are stuck in the inflammation phase and show a cessation of epidermal growth or migration over the wound surface. ${ }^{3}$ The use of newer dressings with collagen dressings may increase the wound-healing potentials. Collagen is a biomaterial that encourages wound healing through deposition and organisation of freshly formed fibres and granulation tissue in the wound bed, thus creating a good environment for wound healing.

The average age distribution of patients in this study was forty seven years. Average age in studies done by Veves et al ${ }^{4}$ and Rao et $\mathrm{al}^{5}$ were comparable to our study, but average age in study by Singh 0 et al $^{6}$ was less than that included in our study, as most of the patients in our studies belonged to low socioeconomic status and were labourers by occupation even in older ages.

The average duration of ulcer in collagen dressing group was 9.2 weeks and in conventional group was 8.8 weeks. This is comparable to the study done by Veves et al. ${ }^{4}$ Most of the ulcers (65\%) were less than $20 \mathrm{~cm}^{2}$, which was quite large as compared to Veves et $\mathrm{al}^{4}$ and Rao et $\mathrm{al}^{5}$

The infection rate in conventional group was much higher than collagen group, which suggests collagen sponge has higher safety profile than that of conventional dressing. This finding was same as that shown by study by Rao et al. ${ }^{5}$

A common characteristic of all chronic wounds is the elevation of the levels of matrix metalloproteinases, which results in increased proteolytic activity and inactivation of the growth factors involved in the wound-healing process. The use of collagen sponge dressing has been shown to specifically inhibit the action of these proteases without affecting the activity of the growth factors. Thus, theoretically, collagen sponge dressing may be an advantageous alternative to the moistened gauze that is the current standard of care.

The average healing time in collagen group was 3 weeks, whereas it was 4.9 weeks in conventional group and p value is 0.002 being highly significant. This has a lot of impact on patient's life. Once healing time is reduced, patient can go back to work. Another factor in collagen group which was satisfying to the patients was that once collagen was completely adherent to their wound and no more lysing they could go back to work and resume normal activities. Their hospital visits were then reduced to once per week for followup. Hence, the quality of life was significantly better in this group. ${ }^{7}$ Healing time was reduced by $39 \%$ in the collagen group. This finding was comparable to other studies, i.e. Veves et $\mathrm{al}^{4}{ }^{4}$ Singh 0 et $\mathrm{al}^{6}$ and Rao et al. ${ }^{5}$

Need of grafting was more in conventional group as compared to collagen in present study as well as studies by Singh $\mathrm{O}$ et $\mathrm{al}^{6}$ and Rao $\mathrm{H}$ et al. ${ }^{5}$

\section{CONCLUSION}

From the above study it was concluded that dressing with collagen granules is associated with early appearance of granulation tissue, better quality of life and less infection rate. So collagen dressing is superior to conventional dressing.

\section{REFERENCES}

[1] Bauling PC. A review of the impact of dressings on quality of life. In: Suggett A, Cherry G, Mani R, et al, eds. Evidence-based wound care: proceedings of a conference sponsored by Smith and Nephew held in York, UK on 17th November 1997. London: Royal Society of Medicine Press 1998:39-42.

[2] Loots MA, Lamme EN, Zeegelaar J, et al. Differences in cellular infiltrate and extracellular matrix of chronic diabetic and venous ulcers versus acute wounds. J Invest Dermatol 1998;111(5):850-7.

[3] Jude EB, Boulton AJ, Ferguson MW, et al. The role of nitric oxide synthase isoforms and arginase in the pathogenesis of diabetic foot ulcers: possible modulatory effects by transforming growth factor beta 1. Diabetologia 1999;42(6):748-57.

[4] Veves A, Sheehan P, Pham HT. A randomized, controlled trial of promogran (a collagen/oxidized regenerated cellulose dressing) vs standard treatment in the management of diabetic foot ulcers. Arch Surg 2002;137(7):822-7.

[5] Rao H, Pai A, Hussein I, et al. A Comparative study between collagen dressings and conventional dressings in wound healing. Int J Collab Res Internal Med \& Public Health 2012;4(5):611-23.

[6] Singh 0, Gupta SS, Soni M, et al. Collagen dressing versus conventional dressing in burn chronic wounds: a retrospective study. J Cutan Aesthet Surg 2011;4(1):126.

[7] Bell E, Erlich HP, Buttle DJ, et al. Living tissue formed in vitro and accepted as skin-equivalent tissue of full thickness. Science 1981;211(4486):1052-4. 